\title{
Plasmids, Biological Properties and Efficacy of Nitrogen Fixation in Rhizobium japonicum Strains Indigenous to Alkaline Soils
}

\author{
By DENNIS C. GROSS ${ }^{1}$, ANNE K. VIDAVER ${ }^{1}$ AND \\ ROBERT V. KLUCAS ${ }^{2}$ \\ ${ }^{1}$ Department of Plant Pathology and ${ }^{2}$ Laboratory of Agricultural Biochemistry, \\ University of Nebraska, Lincoln, Nebraska 68583, U.S.A.
}

(Received 11 December 1978)

\begin{abstract}
Plasmids were isolated from strains of Rhizobium japonicum, predominantly serogroup 135, obtained from soybean nodules collected at 15 sites in Nebraska, U.S.A. In addition to their serotype, these strains were indistinguishable from $R$. japonicum strain 3 IIbl35 in growth rate, sensitivity to phage Rhj781, antibiotic sensitivities, general colony characteristics and rates of nitrogen fixation per plant. All strains occupied soil habitats with similar characteristics, including a high $\mathrm{pH}(7.2$ to 8.3$)$, relatively high conductivity $(0.04$ to $0.32 \mathrm{mS})$, relatively high sodium saturation $(0.32$ to $12.7 \%)$, low iron content $(3.2$ to 14.8 p.p.m.) and low manganese content (5.1 to 18.7 p.p.m.). However, agarose gel electrophoresis analysis of plasmids enabled subdivision of these extra-slow-growing strains into four groups on the basis of differences in plasmid number and size. These strains carried combinations of two or more of four plasmids, ranging in mass from 49 to 118 megadaltons and comprising approximately $20 \%$ of the total DNA per cell. Biological and symbiotic data, along with plasmid analysis, were useful in identifying a wild-type strain (RJ23A) that shows potential as a soybean inoculant in alkaline soils.
\end{abstract}

\section{INTRODUCTION}

Inoculation of soybeans with a strain of Rhizobium japonicum does not necessarily ensure or augment nodulation of roots by that strain. Resident strains frequently induce formation of over $90 \%$ of the nodules despite prior inoculation of seed with agronomically desirable R. japonicum strains (Caldwell \& Vest, 1970; Johnson et al., 1965). Soil pH, soil temperature, planting date and variations in resistance to antagonistic soil microflora have been related to the persistence of particular strains of $R$. japonicum in soil (Caldwell \& Weber, 1970; Drapeau et al., 1973; Ham et al., 1971; Smith \& Miller, 1974; Weber \& Miller, 1972). For example, Ham et al. (1971) substantiated and extended the work of Damirgi et al. (1967), showing that Iowa (U.S.A.) serogroup $135 R$. japonicum strains were significantly associated $(P>0.001)$ with nodules produced by soybeans grown on alkaline soils $(\mathrm{pH} \geqslant 7.5)$ while serogroup 123 predominated in Iowa soils below this $\mathrm{pH}$.

Only two procedures have been commonly used to distinguish and identify strains of R. japonicum - serotyping (Ham et al., 1971; Johnson \& Means, 1963) and bacteriophage typing (Kowalski et al., 1974). Thus, a more definitive means of strain differentiation is desirable. Plasmids from $R$. japonicum have been detected in ethidium bromide-caesium chloride and sucrose gradients (Klein et al., 1975; Luyindula et al., 1975; Nuti et al., 1977), but the number and molecular weights of plasmids in any strain have not been characterized. No phenotypic character(s), including any associated with nodulating ability or 
nitrogen fixation, has been correlated with the presence of plasmids. However, in various fast-growing Rhizobium species and a few cowpea rhizobia, extrachromosomal DNA has been physically isolated and characterized (Bechet \& Guillaume, 1978; Nuti et al., 1977; Tshitenge et al., 1975; Zurkowski \& Lorkiewicz, 1976).

This paper reports the physical characterization of plasmids from strains of $R$. japonicum taken from different alkaline soils in Nebraska, and compares the biological and symbiotic properties of these strains. Plasmid analyses promise to be a means of comparing and identifying strains of $R$. japonicum. Such information, coupled with data on desirable agronomic characteristics, for example, effectiveness of nitrogen fixation or a tendency to thrive in a defined soil habitat, may lead to improved management of seed inoculants.

\section{METHODS}

Bacterial strains. Rhizobium japonicum strains are listed in Tables 1 and 3. Strains 3I1b135, 3I1b117, 3I1 b6 and 3I1b110 were from Dr D. Weber (USDA, Beltsville, Md., U.S.A.), strain WA5099-1-1 was from Dr G. Ham (University of Minnesota, St Paul, Minn., U.S.A.) and the other strains were isolated from nodules of commercially grown soybeans collected in Nebraska. Escherichia coli strains J53(RP1) and DT41(R27) were provided by Dr R. Olsen (University of Michigan, Ann Arbor, Mich., U.S.A.) and strain J53(R1drd19) by Dr S. Falkow (University of Washington, Seattle, Wash., U.S.A.).

Cultivation of bacteria. Rhizobium japonicum strains were maintained on Vincent's (1970) L-arabinose agar slants as described by Gross \& Vidaver (1978). Escherichia coli strains J53(RP1) and DT41(R27) were maintained on nutrient broth/yeast extract (NBY) agar (Vidaver, 1967) containing $25 \mu \mathrm{g}$ tetracycline $\mathrm{ml}^{-1}$; strain $\mathrm{J} 53(\mathrm{R} 1 d r d 19)$ was grown on NBY agar containing $25 \mu \mathrm{g}$ neomycin $\mathrm{ml}^{-1}$.

For culturing rhizobia in liquid, $\mathrm{L}$-arabinose broth $(30 \mathrm{ml}$ in $250 \mathrm{ml}$ flask) was inoculated from slants and aerated on a rotary shaker at $25^{\circ} \mathrm{C}$ and $250 \mathrm{rev}$. $\mathrm{min}^{-1}$. Escherichia coli liquid cultures were grown in NBY broth at $37^{\circ} \mathrm{C}$.

Biological characterization of strains. Exponential phase $R$. japonicum strains in broth cultures were subcultured in duplicate into fresh medium and grown at $25^{\circ} \mathrm{C}$ and $250 \mathrm{rev} \cdot \mathrm{min}^{-1}$. At $24 \mathrm{~h}$ intervals, samples were diluted in sterile buffer $(12.5 \mathrm{~mm}$-potassium phosphate $\mathrm{pH} 7 \cdot 2)$, appropriate dilutions were plated $(100 \mu \mathrm{l})$ on to L-arabinose agar, and after incubation and growth at $30^{\circ} \mathrm{C}$ the number of colony-forming units (c.f.u.) $\mathrm{ml}^{-1}$ was determined. Doubling times were calculated from values interpolated from the growth curves near the beginning and the end of the exponential growth phase (Meynell \& Meynell, 1970).

Rhizobium japonicum strains were tested for bacteriocin production on L-arabinose agar by the procedure of Gross \& Vidaver (1978).

Bacteriophage sensitivity of strains was tested with bacteriophage Rhj781, isolated from soil collected from a soybean field in Nebraska. A stock of purified phage $\left[10^{8}\right.$ to $10^{9}$ plaque-forming units $\left.\mathrm{ml}^{-1}\right]$ was produced and stored as described by Kowalski et al. (1974). The phage-typing procedure of Kowalski et al. (1974) was modified by spotting the stock-phage preparation in $5 \mu \mathrm{l}$ quantities on L-arabinose agar overlaid with $2.5 \mathrm{ml} \mathrm{L}$-arabinose soft agar $(0.7 \%, \mathrm{w} / \mathrm{v})$ containing the test $R$. japonicum strain. The rhizobia were grown in L-arabinose broth to exponential phase, then diluted and mixed $(100 \mu \mathrm{l})$ with the L-arabinose soft agar to give between $5 \times 10^{6}$ and $1 \times 10^{7}$ c.f.u. per plate.

Minimal inhibitory concentrations of antimicrobial agents (chloramphenicol, gentamicin, kanamycin, nalidixic acid, neomycin, penicillin $\mathrm{G}$, streptomycin and tetracycline) were determined for $R$. japonicum strains by the agar dilution method (Washington \& Barry, 1974) using L-arabinose agar medium.

The agglutination procedure of Damirgi et al. (1967) was used to classify strains serologically.

Isolation of rhizobia from nodules. Nodulated 6 to 8 week-old field-grown soybean plants were collected from 22 widely dispersed sites in Nebraska. Roots were rinsed in sterile water and nodules were then excised, surface-sterilized by immersion in $1.2 \%$ (v/v) sodium hypochlorite solution for $10 \mathrm{~min}$, and rinsed with distilled water. As determined by independent checks, this procedure was effective in eliminating detectable surface rhizobia. From each of the 22 collection sites, six nodules were harvested and surveyed for $R$. japonicum type by culturing on L-arabinose agar. Individual colonies were picked and restreaked three times to ensure colony uniformity.

Inoculation and growth of soybeans. Surface-sterilized soybean (Glycine max, cv. Amsoy 71) was inoculated as previously described (Gross \& Vidaver, 1978). One seedling was planted in each container and inoculated $2 \mathrm{~d}$ later with approximately $10^{8}$ bacteria. Control plants received only buffer. Preliminary experiments indicated that the initial inoculant strain could always be recovered and identified from the resulting nodules.

Acetylene reduction assays. Five weeks after inoculation, each $R$. japonicum strain was tested in triplicate on Amsoy 71 for nitrogenase activity by following acetylene reduction using the procedures of Pedersen 
et al. (1978) and Klucas (1974). In these tests, plants grown from surface-sterilized seeds were enclosed in $30.5 \times 61 \mathrm{~cm}$ polypropylene bags that were then injected with $42 \mu \mathrm{mol}$ methane as an internal standard and approx. $0 \cdot 1 \mathrm{~atm}(10 \mathrm{kPa})$ acetylene. Samples $(500 \mu \mathrm{l})$ were taken at intervals and ethylene levels were measured using a Perkin-Elmer model 3920B gas chromatograph equipped with a flame ionization detector and a $3 \mathrm{M}$ Porapak N column. Rates of ethylene production per plant and per mg dry nodule were calculated from the slope of a graph of measurements taken at three $15 \mathrm{~min}$ intervals. All nodules were harvested and dried to constant weight in an $80^{\circ} \mathrm{C}$ oven for determination of dry weight. Sterile 12.5 mm-potassium phosphate buffer, pH 7·2, was substituted for inoculant to obtain nodule-free checks.

In another experiment, relative nodule development was monitored by determining the rates of acetylene reduction at 3, 4 and 5 weeks after inoculation of Amsoy 71 with strains 3I1b135, RJ12S, RJ23A, RJ10B, RJ19FY, RJ17W and 3I1b6.

Soil analyses. Rhizosphere soil samples were obtained from the 22 soybean collection sites described above. After drying, the soil samples were analysed for $\mathrm{pH}$, conductivity, sodium saturation, and manganese and iron concentrations (along with nine other soil characteristics) by the University of Nebraska Soil Testing Laboratory, basically as outlined by Black et al. (1965).

Cell lysis and plasmid isolation. Bacteria were grown in $30 \mathrm{ml}$ medium to between $2 \times 10^{8}$ and $6 \times 10^{8}$ colony-forming units (c.f.u.) $\mathrm{ml}^{-1}$. Rhizobium japonicum and $E$. coli cells were lysed (final vol. $12 \mathrm{ml}$ ) as described by Currier \& Nester (1976) except that Sarkosyl NL30 (ICN Pharmaceuticals, Plainview, N.Y., U.S.A.) was substituted for sodium dodecyl sulphate (SDS). Lysates were sheared in $4 \mathrm{ml}$ amounts and then denatured with alkali. Denatured DNA was removed by phenol treatment, with $1 \mathrm{M}-\mathrm{LiCl}$ substituted for $3 \%(\mathrm{w} / \mathrm{v}) \mathrm{NaCl}$. After two extractions with phenol, 2 vol. $95 \%$ ethanol at $-20{ }^{\circ} \mathrm{C}$ were added to facilitate precipitation of plasmids from the aqueous phase followed by storage of samples for a minimum of $2 \mathrm{~h}$ at $-20^{\circ} \mathrm{C}$.

Agarose gel electrophoresis. Precipitated plasmid DNA was collected by centrifugation (12100 $\mathrm{g}$ for $20 \mathrm{~min}$ ) and the pellet was resuspended in $200 \mu \mathrm{l}$ of a dye solution containing $25 \%(\mathrm{v} / \mathrm{v})$ glycerol, $5 \%(\mathrm{w} / \mathrm{v})$ SDS and $0.025 \%(\mathrm{w} / \mathrm{v})$ bromophenol blue in water. Samples $(5$ to $30 \mu \mathrm{l})$ of plasmid preparations were applied to $0.7 \%$ (w/v) agarose (Sea Kem, Marine Colloids, Rockland, Me., U.S.A.) vertizal slab gels and subjected to electrophoresis (ORTEC model 4200, Oakridge, Tenn., U.S.A.) according to the method of Meyers et al. (1976). The $8 \times 10 \times 0.3 \mathrm{~cm}$ gels had 12 slots for sample placement. Electrophoresis was complete after $3.5 \mathrm{~h}$ with $40 \mathrm{~V}$ supplied by a constant voltage power source. Gels were stained with ethidium bromide $\left(1 \mu \mathrm{g} \mathrm{ml}^{-1}\right.$ in distilled water) for $1 \mathrm{~h}$ and visualized according to Hansen \& Olsen (1978). The average molecular mass was determined according to Meyers et al. (1976) by comparing the relative mobility of R. japonicum plasmids to plasmids RP1 [39 megadaltons (Mdal) (Burkardt et al., 1978)], R1 [62 Mdal (Meyers et al., 1976)] and R27 [112 Mdal (Hansen \& Olsen, 1978)].

Dye-buoyant density equilibrium centrifugation. Exponential phase cells of $R$. japonicum from liquid culture were subcultured in $\mathrm{L}$-arabinose broth $\left(5 \times 10^{7}\right.$ initial c.f.u. $\left.\mathrm{ml}^{-1}\right)$ containing $5 \mu \mathrm{Ci}\left[{ }^{3} \mathrm{H}\right]$ adenine $\mathrm{ml}^{-1}$ (20.2 $\mathrm{Ci} \mathrm{mmol}^{-1}$; New England Nuclear). Bacteria were then grown and lysed as described above.

Concentrated [ ${ }^{3} \mathrm{H}$ ]DNA was dialysed and prepared for caesium chloride-ethidium bromide gradients according to Currier \& Nester (1976). The suspension was centrifuged at $15^{\circ} \mathrm{C}$ in a Spinco Ti50 fixed angle rotor for $60 \mathrm{~h}$ at $40000 \mathrm{rev}$. $\mathrm{min}^{-1}$. Gradients were fractionated from the bottom. Radioactivity was determined after alkali-treated fractions had been precipitated by trichloroacetic acid (Bollum, 1968).

\section{RESULTS}

\section{Geographic distribution of extra-slow-growing $R$. japonicum strains in relation to the soil habitat}

Extra-slow-growing (ESG), non-mucoid R. japonicum strains have doubling times of approximately $14 \mathrm{~h}$ or more (Table 1), while most strains have doubling times of 6 to $13 \mathrm{~h}$ (Vincent, 1977). An exception is the mucoid strain WA5099-1-1 that has a doubling time of approximately $24 \mathrm{~h}$. The geographically diverse soils which yielded these ESG strains have similar mineral and chemical properties (Table 2). Sixteen of the 22 soils analysed were alkaline soils [saline and/or calcareous (Thompson \& Troeh, 1973)], and ESG, non-mucoid $R$. japonicum strains were recovered from soybean nodules produced on 15 of these high $\mathrm{pH}$ soils. Mucoid rhizobia of usual colony morphology (Vincent, 1977) and noticeably faster growth on agar media (and commonly serotype 123) were exclusively recovered from the remaining soils. Nodules containing either or both colony types were found in some soils. However, the prevalence of non-mucoid, ESG strains was generally correlated with a 
Table 1. Characteristics of $R$. japonicum strains

\begin{tabular}{|c|c|c|c|c|c|c|}
\hline Strain no. & Serogroup & $\begin{array}{l}\text { acteriocin } \\
\text { group }\end{array}$ & $\begin{array}{l}\text { Sensitivity } \\
\text { to phage } \\
\text { Rhj781 }\end{array}$ & $\begin{array}{l}\text { Doubling } \\
\text { time (h) }\end{array}$ & $\begin{array}{c}\text { Ethylene } \\
\text { produced } \\
\text { (nmol per } \\
\left.\text { plant } \text { min }^{-1}\right)^{*}\end{array}$ & $\begin{array}{c}\text { Ethylene } \\
\text { produced } \\
(\text { nmol per mg } \\
\text { dry nodule } \mathbf{h}^{-1} \text { )* }\end{array}$ \\
\hline $3 I 1 b 135$ & 135 & 3 & + & $15 \cdot 7$ & $69.3 \mathrm{BC} \dagger$ & $36 \cdot 2 \mathrm{CD} \dagger$ \\
\hline RJ10B & 135 & 3 & + & $19 \cdot 8$ & $88 \cdot 0 \mathrm{BC}$ & $45.0 \mathrm{CD}$ \\
\hline RJ12S & 135 & 3 & + & $20 \cdot 7$ & $87.6 \mathrm{BC}$ & $53 \cdot 3 \mathrm{BC}$ \\
\hline RJ19FY & 135 & 3 & + & $30 \cdot 1$ & $82.0 \mathrm{BC}$ & $41 \cdot 0 \mathrm{CD}$ \\
\hline RJ17W & 135 & 3 & + & $22 \cdot 6$ & $73 \cdot 2 \mathrm{BC}$ & $38.4 \mathrm{CD}$ \\
\hline RJ23A & 135 and 117 & 3 & - & $13 \cdot 4$ & $162 \cdot 4 \mathrm{~A}$ & $67 \cdot 0 \mathrm{~B}$ \\
\hline WA5099-1-1 & 110 & 1 & - & $24 \cdot 1$ & $41 \cdot 1 \mathrm{C}$ & $24 \cdot 3 \mathrm{D}$ \\
\hline $3 \mathrm{I} 1 \mathrm{~b} 6$ & c1 & 1 & - & $10 \cdot 6$ & $112 \cdot 0 \mathrm{AB}$ & $92.8 \mathrm{~A}$ \\
\hline $3 I 1 b 110$ & 110 & 1 & - & $9 \cdot 3$ & $80.7 \mathrm{BC}$ & $69 \cdot 4 \mathrm{~B}$ \\
\hline 4BAL & 123 & 2 & - & $10 \cdot 6$ & $55 \cdot 5 \mathrm{C}$ & $35 \cdot 8 \mathrm{CD}$ \\
\hline $3 I 1 b 117$ & 117 & 1 & - & $11 \cdot 6$ & ND & ND \\
\hline
\end{tabular}

ND, Not determined.

* Determinations completed 5 weeks after inoculation of cultivar Amsoy 71. Each rate is an average of three replications. Plants inoculated with sterile phosphate buffer remained non-nodulated.

$\dagger$ Values followed by identical letters are not significantly different $(P \leqslant 0.05)$ using Duncan's new multiple-range test.

\section{Table 2. Association of extra-slow-growing (ESG) R. japonicum strains with alkaline soils}

Six nodules were obtained from different plants ( 6 to 8 weeks-old) for each soil site and used for isolation of $R$. japonicum. In nodules from soybeans grown in alkaline soils the ESG strains were either found exclusively or mixed in varying proportions (up to $50 \%$ ) with mucoid strains. All $R$. japonicum isolates from nodules of soybeans grown in pH 5.5 to 6.9 soils were mucoid strains.

$\begin{array}{ccccccc}\begin{array}{c}\text { Soil pH } \\ \text { range }\end{array} & \begin{array}{c}\text { No. of } \\ \text { soils }\end{array} & \begin{array}{c}\text { No. yielding } \\ \text { ESG }\end{array} & \begin{array}{c}\text { Conductivity } \\ (\mathrm{mS})\end{array} & \begin{array}{c}\text { Sodium } \\ \text { saturation } \\ (\%)\end{array} & \begin{array}{c}\text { Manganese } \\ \text { (p.p.m.) }\end{array} & \begin{array}{c}\text { Iron } \\ \text { (p.p.m.) }\end{array} \\ 7 \cdot 2-8 \cdot 3 & 16 & 15 & 0 \cdot 040 \cdot 32 & 0 \cdot 32-12 \cdot 70 & 5 \cdot 1-18 \cdot 7 & 3 \cdot 2-14 \cdot 8 \\ 5 \cdot 5-6.9 & 6 & 0 & 0 \cdot 02-0 \cdot 06 & 0 \cdot 02-0 \cdot 93 & 15 \cdot 4-39 \cdot 6 & 16 \cdot 9-72 \cdot 2\end{array}$

higher $\mathrm{pH}$. All soils with resident ESG rhizobia had five common characteristics: high $\mathrm{pH}$, high conductivity and high sodium content but low levels of iron and manganese.

The natural geographic distribution of ESG, non-mucoid strains in Nebraska (Fig. 1) was largely independent of plasmid size and number (determined and discussed below). Isolation from six nodules at each of 15 sites (Table 2) from plants chosen at random showed that the distribution ranged from approximately half to all ESG strains. Each collection site generally yielded ESG strains comprising a single plasmid group. For example, at one collection site, where isolates from each of six nodules were examined for plasmids, all isolates were indistinguishable in plasmid profile. No particular soil factor, such as $\mathrm{pH}$ or iron level, was correlated with the presence of a particular plasmid group.

\section{Isolation and characterization of plasmids}

All ESG strains examined, including strains not listed here, contained plasmids; a representative strain from each collection site is included in Table 3. Plasmids were readily and reproducibly isolated from both ESG and mucoid strains of $R$. japonicum (Table 3 ). These plasmids ranged between 48 and $130 \mathrm{Mdal}$, as assessed by relative electrophoretic mobility on agarose gels (Fig. 2). Of particular significance was the detection of four groups of strains of $R$. japonicum (exemplified by RJ10B, RJ12S, RJ19FY and RJ17W) that carried combinations of two or more of four plasmids (Table 3). The 118 and $91 \mathrm{Mdal}$ plasmids were common to all strains within these four groups; the presence or absence of the 74 and 


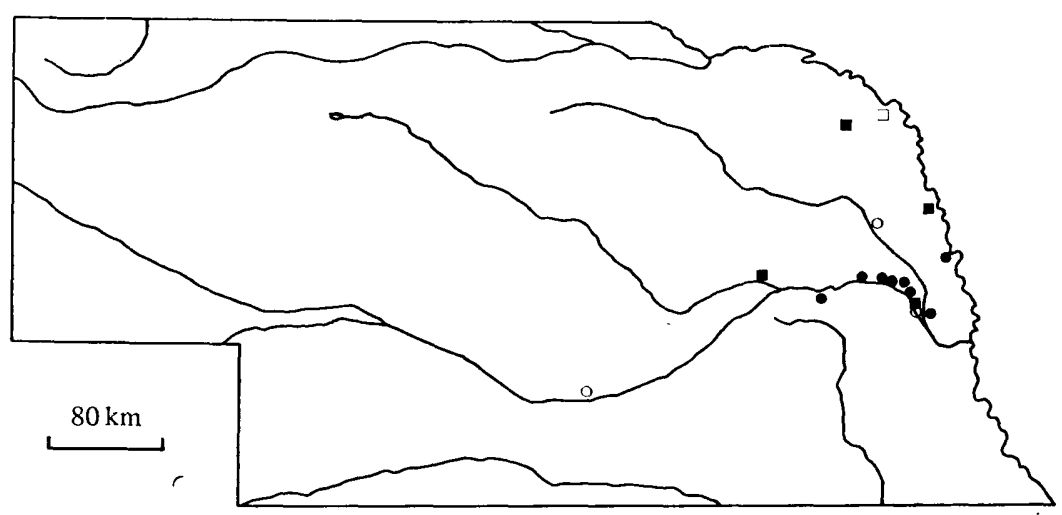

Fig. 1. Geographical distribution of ESG strains of $R$. japonicum in Nebraska, U.S.A. Symbols indicate the plasmid group for strains recovered at a particular site: $\square, 49,74,91$ and 118 Mdal plasmids; $\square, 74,91$ and 118 Mdal plasmids; $0,49,91$ and $118 \mathrm{Mdal}$ plasmids; $\bigcirc, 91$ and $118 \mathrm{Mdal}$ plasmids.

Table 3. Plasmids from R. japonicum strains

\begin{tabular}{lcl} 
Strain no. & $\begin{array}{c}\text { No. of } \\
\text { plasmids* }\end{array}$ & \multicolumn{1}{c}{ Plasmid size (megadaltons)* } \\
3I1b135 & 4 & $48( \pm 1 \cdot 1), 73( \pm 0 \cdot 0), 111( \pm 2 \cdot 1), 115( \pm 0 \cdot 7),[2]$ \\
RJ10B $\dagger$ & 4 & $49( \pm 2 \cdot 5), 74( \pm 3 \cdot 1), 91( \pm 3 \cdot 0), 118( \pm 4 \cdot 1),[10]$ \\
RJ12S & 3 & $74( \pm 3 \cdot 1), 91( \pm 3 \cdot 0), 118( \pm 4 \cdot 1),[10]$ \\
RJ19FY $\ddagger$ & 3 & $49( \pm 2 \cdot 5), 91( \pm 3 \cdot 0), 118( \pm 4 \cdot 1),[10]$ \\
RJ17W & 2 & $91( \pm 3 \cdot 0), 118( \pm 4 \cdot 1),[10]$ \\
RJ23A & 2 & $86( \pm 3 \cdot 7), 99( \pm 2 \cdot 9),[8]$ \\
WA5099-1-1 & 2 & $83( \pm 3 \cdot 6), 116( \pm 7 \cdot 4),[6]$ \\
3I1b117 & 1 & $130( \pm 7 \cdot 5),[5]$
\end{tabular}

* Determined by electrophoretic separation on agarose gels as described in Methods. Numbers in parentheses are the standard deviation of the molecular mass determined for each plasmid. Numbers in brackets refer to the number of replications. The average plasmid size was calculated from these gels.

$\uparrow$ Strains RJ2M, RJ14C and RJ22AY were indistinguishable from RJ10B in the number and size of plasmids.

† Strains RJ5V, RJ6V, RJ7A, RJ8S, RJ9B, RJ20FY and RJ21NH were indistinguishable from RJ19FY in the number and size of plasmids.

$\S$ Strains RJ4G and RJ22AH were indistinguishable from RJ17W in the number and size of plasmids.

49 Mdal plasmids differentiated these groups. Numerous plasmids were detected in other commonly found $R$. japonicum strains. For example, strain $3 I 1 b 135$ had four plasmids but they differed in size from those in strain RJ10B. Only one strain (3I1b117) had a single plasmid; its molecular mass was 130 Mdal (Table 3).

The caesium chloride-ethidium bromide sedimentation profile of plasmids isolated from strain RJ19FY is shown in Fig. 3. More than half of the isolated DNA was separated into a satellite band of covalently closed circular DNA that clearly shows the selective loss of chromosomal DNA while enriching for plasmid DNA. Electrophoresis on agarose gels of the RJ19FY satellite DNA resulted in the separation of the three plasmids (Table 3 ). The ratio of plasmid DNA (recovered in the peak shown in Fig. 3) to total DNA (calculated from radioactivity in the cleared lysate subsamples prior to phenol treatment) was approximately $22 \%$ of the total DNA for strain RJ19FY. Assuming a genome size of approximately $2500 \mathrm{Mdal}$ (Bak et al., 1970) it was estimated there were approximately 1 to 3 copies per cell of each plasmid. Similar dye-buoyant density gradient profiles and plasmid yields were obtained for strain 3I1b135 (not shown). Strains 3I1b6, 3I1 b110 and 4BAL also had plasmids, as determined by separation from chromosomal DNA on caesium chloride-ethidium bromide density gradients. 


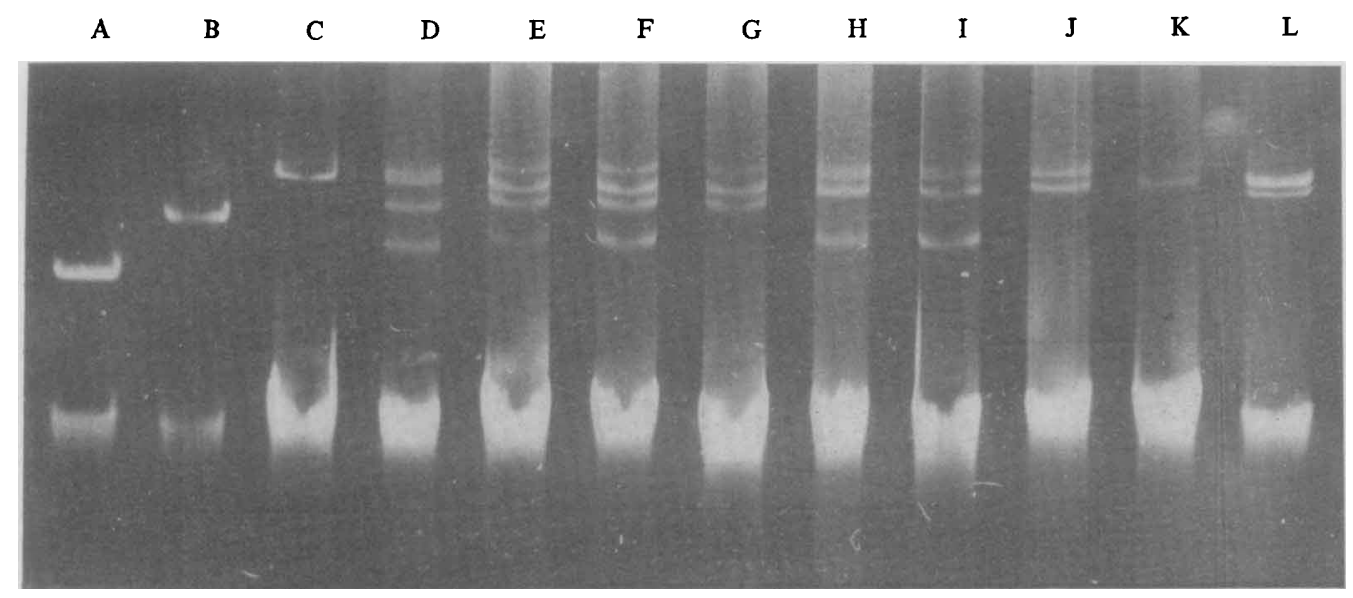

Fig. 2. Agarose gel electrophoresis of plasmids from ESG $R$. japonicum strains and reference plasmids from $E$. coli. Chromosomal fragments were the most rapidly migrating DNA (bottom band). Reference plasmids are: A, RP1 (39 Mdal); B, R1drd19 (62 Mdal); C, R27 (112 Mdal). Plasmid profiles of $R$. japonicum strains are: D, 3I1b135; E, RJ10B; F, RJ14C; G, RJ12S; H, RJ19FY; I, RJ21NH; J, RJ17W; K, RJ4G ; L, RJ23A. Plasmid number and mass for these strains is summarized in Table 3.

\section{Biological and symbiotic properties of $R$. japonicum strains differing in plasmid number and size}

Rhizobium japonicum strains that had different plasmid complements (Table 3 ) varied in their biological and symbiotic properties (Table 1). Despite quantitative or qualitative plasmid differences in strains 3I1b135, RJ10B, RJ12S, RJ19FY and RJ17W, they were all serotype 135, in bacteriocin group 3 (non-producers), sensitive to bacteriophage Rhj781, and ESG (doubling times greater than $14 \mathrm{~h}$ ). These strains also had indistinguishable sensitivity profiles to eight antibiotics, with no significant resistance to any individual antibiotic.

Rates of nitrogen fixation for soybean plants inoculated with strains RJ10B, RJ12S, RJ19FY and RJ17W were similar and appeared to have no relationship to the presence or absence of the 74 and 49 Mdal plasmids (Table 3). All strains identical in plasmid number and size also had approximately the same rate of ethylene production (Table 1). Other commonly used strains of $R$. japonicum that exemplify the diversity of $R$. japonicum by serogroup (four), efficacy of nitrogen fixation (41 to $112 \mathrm{nmol}$ ethylene produced per plant $\mathrm{min}^{-1}$ ) and plasmid size and number are also shown in Table 3.

Strain RJ23A was of particular interest because it had many characteristics in common with the majority of ESG strains including overall colony morphology, a slow growth rate, antibiotic sensitivity profile, lack of bacteriocin production and agglutination with 135 antiserum (Table 1). However, it also reacted with 117 antiserum, was insensitive to bacteriophage Rhj781 and differed in plasmid profile (Table 3). More significantly, it had approximately twice the rate of nitrogen fixation per plant and a greater rate of nitrogen fixation per nodule dry weight than any of the serogroup 135 strains.

Three different plasmid-containing types of ESG strains were compared for nodule development as measured by acetylene reduction (Fig. 4). Strain RJ12S exemplifies the similarity of increase in nitrogen fixation with time for strains RJ10B, RJ19FY and RJ17W. Strain RJ23A was superior in nitrogen fixation to all serogroup 135 strains throughout the 3 week period that represents the early but important stage of symbiosis. Both the ESG strains and the other $R$. japonicum strains formed effective nodules 3 weeks after inoculation. 


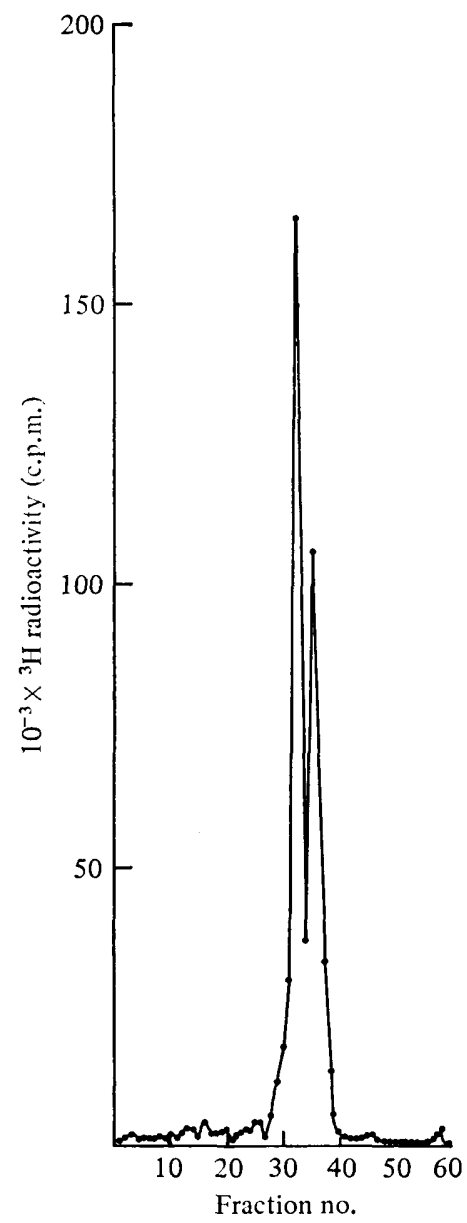

Fig. 3

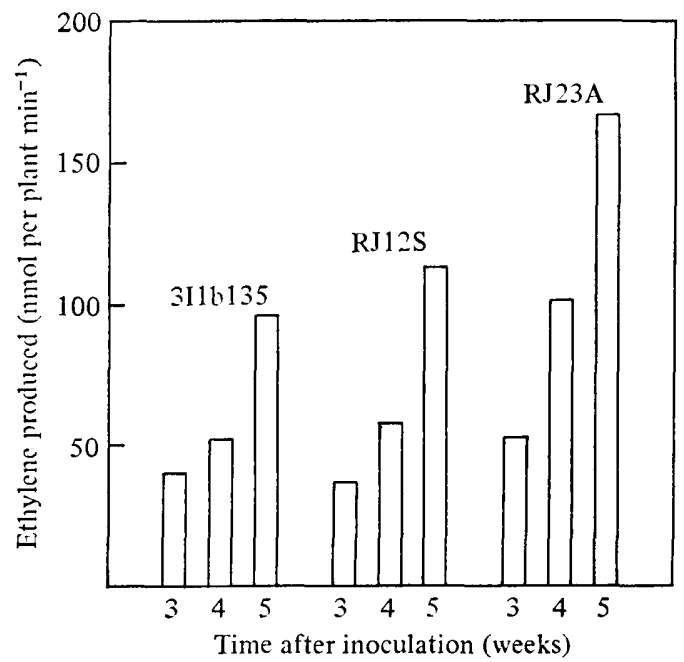

Fig. 4

Fig. 3. Caesium chloride-ethidium bromide density gradient profile of $R$. japonicum $\mathrm{RJ} 19 \mathrm{FY}\left[{ }^{3} \mathrm{H}\right]$ DNA. After reaching equilibrium the gradient was fractionated from the bottom. Fraction 32 contained the plasmid DNA peak and fraction 35 contained the chromosomal DNA peak.

Fig. 4. Relative increase in rate of acetylene reduction 3,4 and 5 weeks after inoculation of Amsoy 71 with $R$. japonicum strains $3 I 1$ b135, RJ12S, and RJ23A. Each bar represents an average rate from four replicated plants.

\section{DISCUSSION}

Analysis of serogroup 135 strains of $R$. japonicum for differences in plasmid number and mass provides a rapid and reliable means of strain distinction. In Nebraska, strains of four plasmid groups were distributed in 15 geographically-distinct alkaline soil sites. Although they all had a 118 and 91 Mdal plasmid in common, they varied in the presence or absence of a 74 and/or $49 \mathrm{Mdal}$ plasmid. The plasmid profiles were not associated with bacteriophage sensitivity, antibiotic sensitivity, doubling time or efficacy of nitrogen fixation on soybean. Phenotypic characteristics have not yet been definitively associated with any plasmids in other Rhizobium species (Nuti et al., 1977; Zurkowski \& Lorkiewicz, 1976), but there is evidence that bacteriocin production and nodulating ability may be plasmid-linked properties in a strain of $R$. leguminosarum (Johnston et al., 1978). Conversely, Cole \& Elkan (1973) inferred that transmissible antibiotic resistance of $R$. japonicum was due to a plasmid(s), but presented no physical evidence. 
All strains of $R$. japonicum were easily lysed by the basic Currier \& Nester (1976) technique and plasmids were readily isolated. These could be quantitatively differentiated. No difference in plasmid recovery from these strains occurred if Hansen \& Olsen's (1978) technique designed for large plasmids was used (unpublished data).

Agarose gel electrophoresis can be used to determine plasmid molecular mass with less than $10 \%$ error (Meyers et al., 1976) and there is linearity of large plasmid migration in gels to approximately $140 \mathrm{Mdal}$ (Hansen \& Olsen, 1978). Since the reference plasmids RP1 (39 Mdal), R1 (62 Mdal) and R27 (112 Mdal) formed a linear standard, an accurate determination of mass was possible for most of the $R$. japonicum plasmids, which range from 48 to $118 \mathrm{Mdal}$. In strains $3 \mathrm{I} 1 \mathrm{bl} 35$ and RJ10B, that had two plasmids of practically the same size, only further studies, such as by restriction endonuclease analysis, will show evidence of identity, if any.

The association of ESG strains of R. japonicum with alkaline soils substantiates earlier observations by Damirgi et al. (1967), Ham et al. (1971) and Kowalski et al. (1974). As shown here, wild-type strains isolated from surface-sterilized nodules could be cloned, inoculated on soybeans and re-isolated from surface-sterilized nodules. In addition, serological, bacteriophage and bacteriocin typing support the observation that these ESG, non-mucoid strains belong to an alkaline soil ecotype and are not mutants (Herridge \& Roughley, 1975; Kuykendall \& Elkan, 1976; Upchurch \& Elkan, 1977). However, a soil of high pH is not considered to be the primary factor responsible for ESG strain success. Cationic effects on growth and viability are well documented (Upchurch \& Elkan 1977; Vincent, 1977). In our study, concentrations of iron and manganese were lowest in fields harbouring ESG strains (alkaline $\mathrm{pH}$ having a negative effect on availability of these cations). Survival in such soils is perhaps related to greater sensitivity of common rhizobia to one or both of these cations. These cations may also affect competitive ability to nodulate soybean. In greenhouse experiments, nodules containing serogroup 135 decreased from 88 to $43 \%$ as iron concentrations in neutral $\mathrm{pH}$ nutrient solutions increased from 0 to 16 p.p.m. (Vest et al., 1973). Our field studies support such results since serogroup 135 rhizobia were not recovered from soils in Nebraska with greater than 16 p.p.m. iron.

Nodules formed by serogroup 135 strains of $R$. japonicum generally had similar and moderate rates of nitrogen fixation. Although soybean cultivar, cultivar age and various environmental conditions can also profoundly affect fixation rates (Eskew \& Schrader, 1977; Klucas \& Arp, 1977), our observed range was consistent with these and other published reports (Carter et al., 1978; Kuykendall \& Elkan, 1976). Plants were inoculated at a neutral $\mathrm{pH}$ but the symbiotic characters effected by strains from alkaline soils were comparable to strains from other soils. Experiments at alkaline $\mathrm{pH}$ may show differences in comparison with common strains isolated from neutral or acidic soils.

Effective nitrogen fixation rates are an important prerequisite for commercial use of R. japonicum strains. Carter et al. (1978) found nodules formed by strain USDA 135 (3I1b135) had a moderate acetylene reduction rate and were moderately efficient (compared with $3 \mathrm{I} 1 \mathrm{~b} 110$ ) in conserving $\mathrm{H}_{2}$, a by-product of nitrogenase activity. However, a strain must be adaptable to and compatible with the habitat in which it is introduced. For example, a phenotypically distinct strain (RJ23A), obtained from an alkaline soil, formed nodules that had a high rate of nitrogen fixation under our test conditions. On a dry nodule weight basis, it was not as effective as $3 \mathrm{I} 1 \mathrm{~b} 6$ or $3 \mathrm{I} 1 \mathrm{~b} 110$ but it supplied more fixed nitrogen to the plant, primarily by virtue of increased nodulation and nodule size. Strain RJ23A thus shows potential as an inoculant to be used in alkaline soils. Besides finding effective wild-type strains, effectiveness of some strains may be increased by mutagenesis (Maier \& Brill, 1978).

Ecological adaptation by $R$. japonicum has not been widely considered in choosing soybean inoculant strains due to a lack of information and definitive tests to differentiate strains. Analysis of plasmids of natural rhizobial populations has provided a useful means to distinguish serogroup 135 strains adapted to an alkaline soil environment. 
This work was supported by USDA-CSRS research agreement no. 516-15-115. We thank Dr R. A. Wiese for providing soil analyses, Dr G. E. Ham for serotyping and Dr C. F. Gonzalez for consultations on plasmid analyses. The skilful technical assistance of Michael B. Keralis, Mitchell Yakrus and Mark Widger is gratefully acknowledged. Published as Paper no. 5691, Journal Series, Nebraska Agricultural Experim ent Station.

\section{REFERENCES}

Bak, A. L., Christiansen, C. \& Stenderup, A. (1970). Bacterial genome sizes determined by DNA renaturation studies. Journal of General Microbiology 64, 377-380.

Bechet, M. \& Guillaume, J. B. (1978). Mise en évidence d'ADN extrachromosomique chez Rhizobium meliloti. Canadian Journal of Microbiology 24, 960-966.

Black, C. A., Evans, D. D., White, J. L., EnsMINGER, L. E. \& ClaRK, F. E. (editors) (1965). Methods of Soil Analysis: Chemical and Microbiological Properties, part 2, pp. 771-1572. Madison, Wisconsin: American Society of Agronomy.

Bollum, F. J. (1968). Filter paper disk techniques for assaying radioactive macromolecules. Methods in Enzymology 12B, 169-173.

Burkardt, H. J., Mattes, R., Puhler, A. \& Heumans, W. (1978). Electron microscopy and computerized evaluation of some partially denatured group $\mathbf{P}$ resistance plasmids. Journal of General Microbiology 105, 51-62.

Caldwell, B. E. \& Vest, G. (1970). Effects of Rhizobium japonicum strains on soybean yields. Crop Science 10, 19-21.

Caldwell, B. E. \& Weber, D. F. (1970). Distribution of Rhizobium japonicum serogroups in soybean nodules as affected by planting dates. Agronomy Journal 62, 12-14.

Carter, K. R., Jennings, N. T., Hanus, J. \& EvaNs, H. J. (1978). Hydrogen evolution and uptake by nodules of soybeans inoculated with different strains of Rhizobium japonicum. Canadian Journal of Microbiology 24, 307-311.

Cole, M. A. \& Elkan, G. H. (1973). Transmissible resistance to penicillin $\mathrm{G}$, neomycin, and chloramphenicol in Rhizobium japonicum. Antimicrobial Agents and Chemotherapy 4, 248-253.

Currier, T. C. \& Nester, E. W. (1976). Isolation of covalently closed circular DNA of high molecular weight from bacteria. Analytical Biochemistry 76, 431-441.

Damirgi, S. M., Frederick, L. R. \& ANDerson, I. C. (1967). Serogroups of Rhizobium japonicum in soybean nodules as affected by soil types. Agronomy Journal 59, 10-12.

Drapeau, R., Fortin, J. A. \& Gagnon, C. (1973). Antifungal activity of Rhizobium. Canadian Journal of Botany 51, 681-682.

EsKew, D. L. \& SCHRADER, L. E. (1977). Effect of $r j_{1} r j_{1}$ (non-nodulating) soybeans on nodulation of near isogenic $R_{j_{1}} R j_{1}$ plants in nutrient culture. Canadian Journal of Microbiology 23, 988-993.

Gross, D. C. \& VIDAVer, A. K. (1978). Bacteriocinlike substances produced by Rhizobium japonicum and other slow-growing rhizobia. Applied and Environmental Microbiology 36, 936-943.
Ham, G. E., Frederick, L. R. \& Anderson, I. C. (1971). Serogroups of Rhizobium japonicum in soybean nodules sampled in Iowa. Agronomy Journal 63, 69-72.

HANSEN, J. B. \& OlsEN, R. H. (1978). Isolation of large bacterial plasmids and characterization of the P2 incompatibility group plasmids pMG1 and pMG5. Journal of Bacteriology 135, 227-238.

Herridge, D. F. \& Roughley, R. J. (1975). Variation in colony characteristics and symbiotic effectiveness of Rhizobium. Journal of Applied Bacteriology 38, 19-27.

Johnson, H. W. \& MEANS, U. M. (1963). Serological groups of Rhizobium japonicum recovered from nodules of soybeans (Glycine max) in field soils. Agronomy Journal 55, 269-271.

Johnson, H. W., Means, U. M. \& Weber, C. R. (1965). Competition for nodule sites between strains of Rhizobium japonicum applied as inoculum and strains in the soil. Agronomy Journal 57, 179-185.

Johnston, A. W. B., Beynon, J. L., BuchananWollaston, A. V., Setchell, S. M., Hirsch, P. R. \& Beringer, J. E. (1978). High frequency transfer of nodulating ability between strains and species of Rhizobium. Nature, London 276, 634636.

Klein, G. E., Jemison, P., HaAk, R. A. \& MatTHYSSE, A. G. (1975). Physical evidence of a plasmid in Rhizobium japonicum. Experientia 31, $532-533$.

KLUCAS, R. V. (1974). Studies on soybean nodule senescence. Plant Physiology 54, 612-616.

Klucas, R. V. \& ARP, D. (1977). Physiological and biochemical studies on senescing tap root nodules of soybeans. Canadian Journal of Microbiology 23, 1426-1432.

Kowalski, M., Ham, G. E., Frederick, L. R. \& ANDERSON, I. C. (1974). Relationship between strains of Rhizobium japonicum and their bacteriophages from soil and nodules of field-grown soybeans. Soil Science 118, 221-228.

Kuykendall, L. D. \& ElkaN, G. H. (1976). Rhizobium japonicum derivatives differing in nitrogen-fixing efficiency and carbohydrate utilization. Applied and Environmental Microbiology 32, 511-519.

Luyindula, N., Tshitenge, G., Lurquin, P. \& Ledoux, L. (1975). Etude des plasmides de Rhizobium japonicum. Archives internationales de physiologie et de biochimie 83, 199-200.

MAIER, R. J. \& BRILL, W. J. (1978). Mutant strains of Rhizobium japonicum with increased ability to fix nitrogen for soybean. Science 201, 448-450.

Meyers, J. A., Sanchez, D., Elwell, L. P. \& FALKow, S. (1976). Simple agarose gel electro- 
phoretic method for the identification and characterization of plasmid deoxyribonucleic acid. Journal of Bacteriology 127, 1529-1537.

Meynell, G. G. \& Meynell, E. (1970). Theory and Practice in Experimental Bacteriology, 2nd edn. Cambridge: Cambridge University Press.

Nuti, M. P., LeDeboer, A. M., LePidi, A. A. \& SCHILPEROORT, R. A. (1977). Large plasmids in different Rhizobium species. Journal of General Microbiology 100, 241-248.

Pedersen, W. L., Chakrabarty, K., Klucas, R. V. \& VIDAVER, A. K. (1978). Nitrogen fixation (acetylene reduction) associated with roots of winter wheat and sorghum in Nebraska. Applied and Environmental Microbiology 35, 129-135.

SMITH, R. S. \& MilleR, R. H. (1974). Interaction between Rhizobium japonicum and soybean rhizosphere bacteria. Agronomy Journal 66, 564-567.

ThOMPSON, L. M. \& Troen, F. R. (1973). Soils and Soil Fertility, 3rd edn, pp. 203-204. New York: McGraw-Hill.

Tshitenge, G., Luyindula, N., LuRquin, P. F. \& LEDOUX, L. (1975). Plasmid deoxyribonucleic acid in Rhizobium vigna and Rhizobium trifolii. Biochimica et biophysica acta 414, 357-361.

UpChURCH, R. G. \& ElKaN, G. H. (1977). Comparison of colony morphology, salt tolerance and effectiveness in Rhizobium japonicum. Canadian Journal of Microbiology 23, 1118-1122.
Vest, G., Weber, D. F. \& Sloger, C. (1973). Nodulation and nitrogen fixation. In Soybeans: Improvement, Production, and Uses, pp. 353-390. Edited by B. E. Caldwell. Madison, Wisconsin: American Society of Agronomy.

VIDAVER, A. K. (1967). Synthetic and complex media for the rapid detection of fluorescence of phytopathogenic pseudomonads: effect of the carbon source. Applied Microbiology 15, 15231524.

Vincent, J. M. (1970). A Manual for the Practical Study of the Root Nodule Bacteria. Oxford: Blackwell Scientific Publications.

VINCENT, J. M. (1977). Rhizobium: general microbiology. In $A$ Treatise on Dinitrogen Fixation, Section III: Biology, pp. 277-366. Edited by R. W. F. Hardy \& W. S. Silver. New York: Johrı Wiley.

WASHINGTON II, J. A. \& BARRY, A. L. (1974). Dilution test procedures. In Manual of Clinical Microbiology, 2nd edn, pp. 410-417. Edited by E. H. Lennette, E. H. Spaulding \& J. P. Truant. Washington: American Society for Microbiology. WeBer, D. F. \& MilLER, V. L. (1972). Effect of soil temperature on Rhizobium japonicum serogroup distribution in soybean nodules. Agronomy Journal 64, 796-798.

ZURKOWSKI, W. \& LoRkIEwICZ, Z. (1976). Plasmid deoxyribonucleic acid in Rhizobium trifolii. Journal of Bacteriology 128, 481-484. 